\section{PEMBERLAKUAN KETENTUAN PIDANA TERHADAP KEJAHATAN BERKAITAN DENGAN LIMBAH BAHAN BERBAHAYA DAN BERACUN ${ }^{1}$ \\ Oleh: Vanessa Rorong ${ }^{2}$ \\ Fonny Tawas ${ }^{3}$ \\ Boby Pinasang ${ }^{4}$}

\section{ABSTRAK}

Penelitian ini dilakukan dengan tujuan untuk mengetahui bagaimana bentuk-bentuk tindak pidana berkaitan dengan limbah bahan berbahaya dan beracun dan bagaimana pemberlakuan ketentuan pidana terhadap kejahatan berkaitan dengan limbah bahan berbahaya dan beracun. Dengan menggunakan metode penelitian yuridis normatif, disimpulkan: 1. Bentuk-bentuk tindak pidana berkaitan dengan limbah bahan berbahaya dan beracun, seperti perbuatan melakukan pengelolaan limbah B3 tanpa izin dan perbuatan yang menghasilkan limbah B3 dan tidak melakukan pengelolaan serta memasukkan limbah B3 ke dalam wilayah Negara Kesatuan Republik Indonesia dan memasukkan B3 yang dilarang menurut peraturan perundang-undangan ke dalam wilayah Negara Kesatuan Republik Indonesia, khususnya di bidang Perlindungan dan Pengelolaan Lingkungan Hidup. 2. Pemberlakuan ketentuan pidana terhadap kejahatan berkaitan dengan limbah bahan berbahaya dan beracun, maka pelaku dapat dikenakan pidana penjara dan denda sesuai dengan bentuk-bentuk perbuatan pidana yang telah terbukti secara sah menurut hukum dilakukan oleh pelakunya. Apabila tindak pidana lingkungan hidup dilakukan oleh, untuk, atau atas nama badan usaha, tuntutan pidana dan sanksi pidana dijatuhkan kepada: badan usaha; dan/atau orang yang memberi perintah untuk melakukan tindak pidana tersebut atau orang yang bertindak sebagai pemimpin kegiatan dalam tindak pidana tersebut, sebagaimana diatur dalam Undang-Undang Nomor 32 Tahun 20009 tentang Perlindungan dan Pengelolaan Lingkungan Hidup.

\footnotetext{
${ }^{1}$ Artikel Skripsi

${ }^{2}$ Mahasiswa pada Fakultas Hukum Unsrat, NIM. 16071101465

${ }^{3}$ Fakultas Hukum Unsrat, Magister IImu Hukum

${ }^{4}$ Fakultas Hukum Unsrat, Magister IImu Hukum
}

Kata kunci: Pemberlakuan Ketentuan Pidana, Kejahatan, Limbah Bahan Berbahaya Dan Beracun.

\section{PENDAHULUAN}

\section{A. Latar Belakang}

Berdasarkan Undang-Undang Nomor 32 tahun 2009 Pasal 1 ayat 2 menyatakan bahwa perlindungan dan pengelolaan lingkungan hidup adalah upaya sistematis dan terpadu yang dilakukan untuk melestarikan fungsi lingkungan hidup dan mencegah terjadinya pencemaran dan/atau kerusakan lingkungan hidup yang meliputi perencanaan, pemanfaatan, pengendalian, pemeliharaan, pengawasan, dan penegakan hukum. Peraturan Pemerintah No 18 tahun 1999 Pasal 1 ayat 2 menyatakan Limbah Bahan Berbahaya dan Beracun (B3), adalah sisa suatu usaha dan/atau kegiatan yang mengandung bahan berbahaya dan/atau beracun yang karena sifat dan/atau konsentrasinya dan/atau jumlahnya, baik secara langsung maupun tidak langsung, dapat mencemarkan dan/atau merusakkan lingkungan hidup, dan/atau dapat membahayakan lingkungan hidup, kesehatan, kelangsungan hidup manusia serta makhluk hidup lain. ${ }^{5}$

Sesuai dengan Undang-Undang No. 8 Tahun 1981 tentang Hukum Acara Pidana dinyatakan bahwa penyidikan tindak pidana merupakan sub sistem atau bagian yang tidak terpisahkan dari Sistem Peradilan Pidana Terpadu. Proses penegakan hukum pidana merupakan satu rangkaian proses hukum yang dimulai dari tahapan penyelidikan, penyidikan, penuntutan dan pengadilan. Proses penyidikan tindak pidana di bidang perlindungan dan pengelolaan lingkungan hidup dilaksanakan melalui tahap penyelidikan, penindakan, pemeriksaan serta penyelesaian dan penyerahan berkas perkara. Esensi dari penyelidikan di bidang perlindungan dan pengelolaan lingkungan hidup dilakukan dengan kegiatan mengumpulkan bahan dan keterangan. $^{6}$

\footnotetext{
${ }^{5}$ Evi Malia dan Ardiani Vika A. Peranan Dinas Lingkungan Hidup Dalam Pengawasan Penerapan Akuntansi Lingkungan Pada Entitas Bisnis di Kabupaten Pamekasan.Jurnal Akuntansi Universitas Jember. Vol. 17 No. 2 (2019) hlm. 92-93.

${ }^{6}$ Ibid. hlm. 180.
} 
Penegakan hukum lingkungan kepidanaan tidak lain adalah penegakan terhadap ketentuan-ketentuan pidana dari hukum lingkungan. Substansi, wewenang kelembagaan, dan prosedur yang digunakan secara umum tunduk pada ketentuan hukum lingkungan kecuali jika hal itu belum diatur secara khusus. Dalam hal demikian, maka yang digunakan adalah ketentuan yang berlaku dalam hukum pidana pada umumnya, misalnya mengenai lembaga peradilan, personil, dan hukum acara yang berlaku. ${ }^{7}$

\section{B. Rumusan Masalah}

1. Bagaimanakah bentuk-bentuk tindak pidana berkaitan dengan limbah bahan berbahaya dan beracun?

2. Bagaimanakah pemberlakuan ketentuan pidana terhadap kejahatan berkaitan dengan limbah bahan berbahaya dan beracun?

\section{Metode Penelitian}

Metode penelitian hukum normatif digunakan untuk menyusun penulisan ini. Data sekunder yang digunakan diperoleh melalui studi kepustakaan. Data sekunder terdiri dari bahan hukum primer ialah: peraturan perundang-undangan di bidang perlindungan dan pengelolaan lingkungan hidup. Bahan hukum sekunder terdiri dari literatur-literatur, jurnal hukum dan artikel hukum yang relevan dengan penulisan ini serta bahan hukum tersier terdiri dari kamus umum dan kamus hukum. Bahan hukum primer dan sekunder dianalisis secara normatif kualitatif.

\section{PEMBAHASAN}

\section{A. Bentuk-Bentuk Tindak Pidana Berkaitan Dengan Limbah Bahan Berbahaya Dan Beracun}

Limbah B3 dapat mencemari tanah, air permukaan, air tanah, udara, atau media lainnya dengan berbagai cara, dan dengan berbagai cara pula dapat masuk ke dalam tubuh manusia. Dam-pak yang ditimbulkan limbah B3 apabila masuk ke dalam tubuh manusia sangat beragam. Mulai dari gangguan/kerusakan pada jaringan tubuh dan jaringan saraf hingga berujung pada disfungsi

\footnotetext{
${ }^{7}$ Ibid.
}

organ tubuh, kecacatan, bahkan kematian. Salah satu kejadian yang sering dijadikan contoh atas bahaya limbah B3 terhadap manusia adalah kasus Minamata yang terjadi di Jepang pada tahun 50 -an. Setidaknya 46 orang meninggal dan 3000 warga terpapar limbah merkuri yang dibuang sejak tahun 1932 oleh sebuah perusahaan pupuk ke perairan Teluk Minamata. Merkuri bertrans-formasi menjadi gugus metil yang mengendap di dasar perairan dan bersifat bioakumulatif di dalam tubuh ikan dan kerang yang dikonsumsi oleh para korban. ${ }^{8}$

Undang-Undang Nomor 32 Tahun 20009 tentang Perlindungan dan Pengelolaan Lingkungan Hidup. Pasal 102, 103, 106 dan 107. Pasal 102. Setiap orang yang melakukan pengelolaan limbah B3 tanpa izin.

Penggunaan izin sebagai instrumen pengawasan ditunjukkan dengan pemberian izin-izin tertentu bagi aktivitas masyarakat. Berbagai persyaratanpersyaratan dalam pengurusan izin merupakan pengendali dalam memfungsikan izin itu sebagai alat untuk mengawasi aktivitas masyarakat, dan perbuatan yang dimintakan izin adalah perbuatan yang memerlukan pengawasan khusus. $^{9}$

Pengawasan dibutuhkan sebagai perlindungan hukum bagi warga negara terhadap dampak dari penerbitan keputusan tata usaha negara. Pemerintah menjalankan pemerintahan melalui pengambilan keputusan pemerintahan yang bersifat strategis, policy atau ketentuan-ketentauan umum melalui tindakan-tindakan pemerintahan yang bersifat menegakkan ketertiban umum, hukum, wibawa negara, dan kekuasaan negara. ${ }^{10}$

Izin (Vergunning) adalah suatu persetujuan dari penguasa berdasarkan undang-undang atau peraturan pemerintah untuk dalam keadaan tertentu menyimpang dari ketentuanketentuan larangan peraturan perundangundangan. Izin dapat juga diartikan sebagai dispensasi atau pelepasan/pembebasan dari suatu larangan. ${ }^{11}$

\footnotetext{
${ }^{8}$ Teddy Prasetiawan. Op.Cit. hlm.142.

9 Robinson Parsaoran Sitompul, Susilo Handoyo dan Roziqin. Op.Cit. hlm. 11-12.

${ }^{10}$ Ibid. hlm. 12.

${ }^{11}$ Adrian Sutedi. Hukum Perizinan Dalam Sektor Pelayanan

Publik, Sinar Grafika. Jakarta. 2011, hlm.167-168.
} 
Perizinan adalah salah satu bentuk pelaksanaan fungsi pengaturan dan bersifat pengendalian yang dimiliki oleh pemerintah terhadap kegiatan-kegiatan yang dilakukan oleh masyarakat. Dengan memberikan izin, penguasa memperkenankan orang yang memohonnya untuk melakukan tindakantindakan tertentu yang sebenarnya dilarang demi memperhatikan kepentingan umum yang mengharuskan adanya pengawasan. Hal pokok pada izin, bahwa sesuatu tindakan dilarang kecuali diperkenankan dengan tujuan agar dalam ketentuan-ketentuan yang bersangkutan dilakukan dengan cara-cara tertentu. ${ }^{12}$

Undang-Undang Nomor 32 Tahun 20009 tentang Perlindungan dan Pengelolaan Lingkungan Hidup. Pasal 103. Setiap orang yang menghasilkan limbah B3 dan tidak melakukan pengelolaan sebagaimana dimaksud dalam Pasal 59. Pengelolaan Limbah Bahan Berbahaya dan Beracun Pasal 59 ayat:

(1) Setiap orang yang menghasilkan limbah B3 wajib melakukan pengelolaan limbah B3 yang dihasilkannya.

(2) Dalam hal B3 sebagaimana dimaksud dalam Pasal 58 ayat (1) telah kedaluwarsa, pengelolaannya mengikuti ketentuan pengelolaan limbah B3.

(3) Dalam hal setiap orang tidak mampu melakukan sendiri pengelolaan limbah B3, pengelolaannya diserahkan kepada pihak lain.

(4) Pengelolaan limbah B3 wajib mendapat izin dari Menteri, gubernur, atau bupati/walikota sesuai dengan kewenangannya.

(5) Menteri, gubernur, atau bupati/walikota wajib mencantumkan persyaratan lingkungan hidup yang harus dipenuhi dan kewajiban yang harus dipatuhi pengelola limbah B3 dalam izin.

(6) Keputusan pemberian izin wajib diumumkan.

(7) Ketentuan lebih lanjut mengenai pengelolaan limbah B3 diatur dalam Peraturan Pemerintah.

Penjelasan Pasal 59 ayat (1) Pengelolaan limbah B3 merupakan rangkaian kegiatan yang mencakup pengurangan, penyimpanan, pengumpulan, pengangkutan, pemanfaatan,

\footnotetext{
${ }^{12}$ Ibid, hlm. 168.
}

dan/atau pengolahan, termasuk penimbunan limbah B3. Ayat (3) Yang dimaksud dengan pihak lain adalah badan usaha yang melakukan pengelolaan limbah B3 dan telah mendapatkan izin.

Izin; pernyataan mengabulkan (tiada melarang dan sebagainya) persetujuan membolehkan. ${ }^{13}$ Izin adalah suatu persetujuan dari penguasa berdasarkan peraturan perundang-undangan dan peraturan pemerintah. Dengan demikian izin pada prinsipnya memuat larangan, persetujuan yang merupakan dasar pengecualian. Pengecualian itu harus diberikan oleh undang-undang untuk menunjukkan legalitas sebagai suatu ciri negara hukum yang demokrasi. ${ }^{14}$

Dalam Hukum Administrasi, izin merupakan instrumen yuridis yang digunakan oleh pemerintah untuk mempengaruhi para warga agar mau mengikuti cara yang dianjurkan guna mencapai suatu tujuan konkrit. Sebagai suatu instrumen hukum, izin berfungsi sebagai ujung tombak atau alat yang bertujuan untuk mengarahkan, mengendalikan, merekayasa, dan merancang masyarakat adil makmur. Melalui izin dapat diketahui bagaimana gambaran masyarakat adil makmur itu terwujud, yang berarti persyaratan-persyaratan yang terkandung dalam izin merupakan pengendali dalam memfungsikan izin itu sendiri. ${ }^{15}$

Undang-Undang Nomor 32 Tahun 20009 tentang Perlindungan dan Pengelolaan Lingkungan Hidup. Pasal 106. Setiap orang yang memasukkan limbah B3 ke dalam wilayah Negara Kesatuan Republik Indonesia sebagaimana dimaksud dalam Pasal 69 ayat (1) huruf (d). Pasal 107. Setiap orang yang memasukkan B3 yang dilarang menurut peraturan perundang-undangan ke dalam wilayah Negara Kesatuan Republik Indonesia sebagaimana dimaksud dalam Pasal 69 ayat (1) huruf (b).

Penjelasan Pasal 69 ayat (1) huruf (b) B3 yang dilarang dalam ketentuan ini, antara lain, $D D T, P C B s$, dan dieldrin. Huruf (c) Larangan

\footnotetext{
${ }^{13}$ Sudarsono, Kamus Hukum, Cetakan Keenam, PT. Rineka Cipta, Jakarta, 2009, hlm. 189.

${ }^{14} \mathrm{H}$. Juniarso Ridwan dan Achmad Sodik Sudrajat. Hukum Adminsitrasi Negara dan Kebijakan Pelayanan Publik, Cetakan I. Nuansa. Bandung. 2010.hlm. 92.

${ }^{15}$ Ridwan. HR. Hukum Administrasi Negara. UII Press. Yogyakarta. 2003. hlm. 160.
} 
dalam ketentuan ini dikecualikan bagi yang diatur dalam peraturan perundang-undangan. Huruf (d) Yang dilarang dalam huruf ini termasuk impor. Ayat (2) Kearifan lokal yang dimaksud dalam ketentuan ini adalah melakukan pembakaran lahan dengan luas lahan maksimal 2 hektare per kepala keluarga untuk ditanami tanaman jenis varietas lokal dan dikelilingi oleh sekat bakar sebagai pencegah penjalaran api ke wilayah sekelilingnya.

Menurut Ali Mahrus, perbuatan pidana menunjuk pada perbuatan baik secara aktif maupun secara pasif, sedangkan apakah pelaku ketika melakukan perbuatan pidana patut dicela atau memiliki kesalahan, bukan merupakan wilayah perbuatan pidana, tetapi sudah masuk pada pertanggungjawaban pidana. $^{16}$

Tindak pidana, yaitu: setiap perbuatan yang diancam hukuman sebagai kejahatan atau pelanggaran baik yang disebut dalam KUHPidana maupun peraturan perundangundangan lainnya. ${ }^{17}$ Perbuatan pidana adalah perbuatan yang dilarang oleh suatu aturan hukum, larangan mana disertai ancaman (sanksi) yang berupa pidana tertentu, bagi barang siapa yang melanggar larangan tersebut. $^{18}$ Dapat juga dikatakan bahwa perbuatan pidana adalah perbuatan oleh suatu aturan hukum dilarang dan diancam pidana, asal saja dalam pada itu diingat bahwa larangan ditujukan kepada perbuatan (yaitu suatu keadaan atau kejadian yang ditimbulkan oleh kelakuan orang), sedangkan ancaman pidananya ditujukan kepada orang yang menimbulkan kejadian itu. ${ }^{19}$

\section{B. Pemberlakuan Ketentuan Pidana Terhadap Kejahatan Berkaitan Dengan Limbah Bahan Berbahaya Dan Beracun}

$\mathrm{Di}$ Indonesia, regulasi yang mengatur tentang perlindungan hidup diatur dalam Undang-Undang No. 32 tahun 2009 tentang Perlindungan dan Pengelolaan Lingkungan

\footnotetext{
${ }^{16}$ Ali Mahrus, Dasar-Dasar Hukum Pidana, Cetakan Pertama, Sinar Grafika, Jakarta, 2011.hlm. 97.

${ }^{17}$ Rocky Marbun, Deni Bram, Yuliasara Isnaeni dan Nusya A., Kamus Hukum Lengkap (Mencakup Istilah Hukum \& Perundang-Undangan Terbaru, Cetakan Pertama, Visimedia, Jakarta. 2012, hlm. 311.

${ }_{18}$ Moeljatno, Asas-Asas Hukum Pidana, Edisi Revisi, PT. Rineka Cipta, Jakarta, 2008, hlm. 59

${ }^{19}$ Ibid.
}

Hidup. Di dalam regulasi itu, ada 3 cara penegakan hukum yang bisa dilakukan dalam upaya perlindungan lingkungan hidup.Tiga penegakan hukum itu adalah :

1. Penegakan hukum administratif;

2. Penegakan hukum pidana;

3. Penegakan hukum perdata. ${ }^{20}$

Undang-Undang Nomor 32 Tahun 20009 tentang Perlindungan dan Pengelolaan Lingkungan Hidup. Pasal 103. Setiap orang yang menghasilkan limbah B3 dan tidak melakukan pengelolaan sebagaimana dimaksud dalam Pasal 59, dipidana dengan pidana penjara paling singkat 1 (satu) tahun dan paling lama 3 (tiga) tahun dan denda paling sedikit Rp1.000.000.000,00 (satu miliar rupiah) dan paling banyak Rp3.000.000.000,00 (tiga miliar rupiah).

Undang-Undang Nomor 32 Tahun 20009 tentang Perlindungan dan Pengelolaan Lingkungan Hidup. Pasal 106. Setiap orang yang memasukkan limbah B3 ke dalam wilayah Negara Kesatuan Republik Indonesia sebagaimana dimaksud dalam Pasal 69 ayat (1) huruf $d$, dipidana dengan pidana penjara paling singkat 5 (lima) tahun dan paling lama 15 (lima belas) tahun dan denda paling sedikit Rp5.000.000.000,00 (lima miliar rupiah) dan paling banyak Rp15.000.000.000,00 (lima belas miliar rupiah).

Pasal 107. Setiap orang yang memasukkan B3 yang dilarang menurut peraturan perundang-undangan ke dalam wilayah Negara Kesatuan Republik Indonesia sebagaimana dimaksud dalam Pasal 69 ayat (1) huruf b, dipidana dengan pidana penjara paling singkat 5 (lima) tahun dan paling lama 15 (lima belas) tahun dan denda paling sedikit Rp5.000.000.000,00 (lima miliar rupiah) dan paling banyak Rp15.000.000.000,00 (lima belas miliar rupiah).

Jadi dapat disimpulkan bahwa tujuan hukum pidana adalah untuk melindungi masyarakat. Apabila seseorang takut untuk melakukan perbuatan tidak baik, karena takut dihukum,

\footnotetext{
${ }^{20}$ M. Nurdin. Op.Cit. hlm. 174 (Lihat Syahrul Machmud, Penegakan Hukum Lingkungan Indonesia Penegakan Hukum Administrasi, Hukum Perdata, Hukum Pidana Menurut Undang-Undang No. 32 Tahun 2009, Cetakan 1. Graha Ilmu, Yogyakarta 2012, hlm. 78).
} 
semua orang dalam masyarakat akan tenteram dan aman. ${ }^{21}$

Undang-Undang Nomor 32 Tahun 20009 tentang Perlindungan dan Pengelolaan Lingkungan Hidup. Pasal 116 ayat:

(1) Apabila tindak pidana lingkungan hidup dilakukan oleh, untuk, atau atas nama badan usaha, tuntutan pidana dan sanksi pidana dijatuhkan kepada:

a. badan usaha; dan/atau

b. orang yang memberi perintah untuk melakukan tindak pidana tersebut atau orang yang bertindak sebagai pemimpin kegiatan dalam tindak pidana tersebut.

(2) Apabila tindak pidana lingkungan hidup sebagaimana dimaksud pada ayat (1) dilakukan oleh orang, yang berdasarkan hubungan kerja atau berdasarkan hubungan lain yang bertindak dalam lingkup kerja badan usaha, sanksi pidana dijatuhkan terhadap pemberi perintah atau pemimpin dalam tindak pidana tersebut tanpa memperhatikan tindak pidana tersebut dilakukan secara sendiri atau bersama-sama.

Pasal 117. Jika tuntutan pidana diajukan kepada pemberi perintah atau pemimpin tindak pidana sebagaimana dimaksud dalam Pasal 116 ayat (1) huruf $b$, ancaman pidana yang dijatuhkan berupa pidana penjara dan denda diperberat dengan sepertiga.

Pasal 118. Terhadap tindak pidana sebagaimana dimaksud dalam Pasal 116 ayat (1) huruf a, sanksi pidana dijatuhkan kepada badan usaha yang diwakili oleh pengurus yang berwenang mewakili di dalam dan di luar pengadilan sesuai dengan peraturan perundang-undangan selaku pelaku fungsional.

Pasal 119. Selain pidana sebagaimana dimaksud dalam Undang-Undang ini, terhadap badan usaha dapat dikenakan pidana tambahan atau tindakan tata tertib berupa:

a. perampasan keuntungan yang diperoleh dari tindak pidana;

b. penutupan seluruh atau sebagian tempat usaha dan/atau kegiatan;

c. perbaikan akibat tindak pidana;

d. pewajiban mengerjakan apa yang dilalaikan tanpa hak; dan/atau e. penempatan perusahaan di bawah pengampuan paling lama 3 (tiga) tahun.

Pasal 120 ayat:

(1) Dalam melaksanakan ketentuan sebagaimana dimaksud dalam Pasal 119 huruf $a$, huruf $b$, huruf $c$, dan huruf $d$, jaksa berkoordinasi dengan instansi yang bertanggung jawab di bidang perlindungan dan pengelolaan lingkungan hidup untuk melaksanakan eksekusi.

(2) Dalam melaksanakan ketentuan sebagaimana dimaksud dalam Pasal 119 huruf e, Pemerintah berwenang untuk mengelola badan usaha yang dijatuhi sanksi penempatan di bawah pengampuan untuk melaksanakan putusan pengadilan yang telah berkekuatan hukum tetap.

Ketentuan pidana dalam UU PPLH yang merupakan lex specialist terhadap seluruh pengaturan hukum bidang lingkungan hidup dan menjadi dasar dalam penegakan hukum pidana terhadap pencemaran dan perusakan lingkungan hidup diatur dalam Bab XV dari Pasal 97 sampai dengan 120 UU PPLH. Adapun ketentuan Pasal 97 UU PPLH menyebutkan bahwa "Tindak pidana dalam undang-undang ini merupakan kejahatan". 22

Tindak pidana yang diperkenalkan dalam UUPPLH juga dibagi dalam delik formil dan delik materil. Menurut Sukanda Husin delik materil dan delik formil dapat didefensikan sebagai berikut:

a. Dellik materil (generic crime) adalah perbuatan melawan hukum yang menyebabkan pencemaran atau perusakan lingkungan hidup yang tidak perlu memerlukan pembuktian pelanggaran aturan-aturan hukum administrasi seperti izin.

b. Delik formil (specific crime) adalah perbuatan yang melanggar hukum terhadap aturan-aturan hukum administrasi, jadi untuk pembuktian terjadinya delik formil tidak diperlukan pencemaran atau perusakan lingkungan hidup seperti delik materil, tetapi cukup dengan membuktikan pelanggaran hukum administrasi. ${ }^{23}$

\footnotetext{
${ }^{22} \mathrm{Ibid}$. hlm. 176.

${ }^{23}$ Ibid. hlm. 177 (Lihat Sukanda Husin, Penegakan Hukum Lingkungan Indonesia. Sinar Grafika, Jakarta. 2009. hlm 122). 
Penegakan hukum harus ditingkatkan, hukum harus mampu menjelaskan kriteria baku dari pada kerusakan lingkungan hidup dan karena kasus kerusakan lingkungan hidup oleh limbah industri/perusahaan lebih disebabkan oleh pemahaman terhadap batas kerusakan dan dampak yang ditimbulkan tidak diantisipasi oleh ketentuan atau undang-undang pengelolaan lingkungan hidup. Dengan undangundang perlindungan dan pengelolaan lingkungan hidup yang telah disempurnakan ini diharapkan semua permasalahan lingkungan hidup dapat diselesaikan dengan baik dan tuntas, para pelaku dapat dikenakan pidana setimpal dengan perbuatannya. ${ }^{24}$

Penegakan hukum (pidana) meliputi tiga tahap.Tahap pertama, tahap formulasi yakni tahap penegakan hukum in abtracto oleh badan pembuat undang-undang (tahap legislatif).Tahap kedua, tahap aplikasi yakni tahap penerapan hukum pidana oleh para aparat penegak hukum mulai dari kepolisian, kejaksaan sampai pengadilan (tahap yudikatif).Tahap ketiga, tahap eksekusi, yakni tahap pelaksanaan hukum pidana secara konkret oleh aparat-aparat pelaksana pidana (tahap eksekutif atau administrasi). ${ }^{25}$

Penegakan hukum dijalankan untuk menjaga, mengawal dan menghantar hukum agar tetap tegak searah dengan tujuan hukum dan tidak dilanggar oleh siapapun. Kegiatan penegakan hukum merupakan tindakan penerapan hukum terhadap setiap orang yang perbuatannya menyimpang dan bertentangan dengan norma hukum, artinya hukum diberlakukan bagi siapa saja dan pemberlakuannya sesuai dengan mekanisme dan cara dalam sistem penegakan hukum yang telah ada. ${ }^{26}$ Dengan kata lain penegakan hukum sebagai suatu kegiatan untuk menjaga dan mengawal hukum agar tetap tegak sebagai suatu norma yang mengatur kehidupan manusia demi terwujudnya ketertiban, kemanan dan ketentraman masyarakat dalam menjalankan kehidupannya. ${ }^{27}$

\footnotetext{
24 Robinson Parsaoran Sitompul, Susilo Handoyo dan Roziqin. Op.Cit.hlm. 2-3.

${ }^{25}$ Aziz Syamsuddin. Tindak Pidana Khusus. Sinar Grafika. Jakarta. 2011. hlm. 2-3.

${ }^{26}$ Sadjijono. Polri Dalam Perkembangan Hukum Di Indonesia, (Editor) M. Khoidin, LaksBang PRESSindo, Yogyakarta. 2008. hlm. 61.

${ }_{27}$ Ibid. hlm. 62.
}

Di dalam proses penegakan hukum, negara menjadi pihak yang bertanggungjawab terhadap komitmen bersama sebagai negara berdasar atas hukum, karena itu negara bertanggungjawab atas ketertiban, keamanan dan ketentraman warganegaranya yang merupakan tugas dan wewenang awal dan tradisional dari pemerintah atau negara yang kemudian didelegasikan kepada lembagalembaga hukum. ${ }^{28}$

Salah satu aspek penting dari penerapan suatu kaidah hukum adalah penegakkan hukum (law enforcement). Suatu perangkat hukum baru dapat dikatakan efektif apabila hukum tersebut dapat diimplementasikan dan penerapan sanksinya dapat ditegakan apabila ada yang melanggarnya. Untuk dapat ditegakkan maka di dalam perangkat hukum itu perlu ada suatu mekanisme yang mengatur dan menetapkan bagaimana norma-norma itu ditegakan. Penegakan hukum pada intinya adalah serangkaian kegiatan untuk menyerasikan hubungan nilai-nilai yang terjabarkan di dalam kaidah-kaidah yang mantap dan mengenjawatankannya dengan sikap dan tidak sebagai rangkaian penjabaran nilai-nilai tahap akhir, untuk menciptakan, memelihara dan mempertahankan kedamaian dalam pergaulan hidup. ${ }^{29}$

"Negara Indonesia adalah Negara Hukum". Hal ini di tegaskan dalam Pasal 1 ayat (3) Undang-Undang Dasar 1945. Norma ini bermakna bahwa di dalam negara kesatuan Republik Indonesia, hukum merupakan urat nadi seluruh aspek kehidupan. Hukum mempunyai posisi strategis dan dominan dalam kehidupan masyarakat berbangsa dan bernegara. Hukum, sebagai suatu sistem, dapat berperan dengan baik dan benar di tengah masyarakat jika instrumen pelaksanaannya dilengkapi dengan kewenangan-kewenangan dalam bidang penegakan hukum. ${ }^{30}$

\section{PENUTUP}

\section{A. Kesimpulan}

\footnotetext{
${ }^{28} \mathrm{Ibid}$.

${ }^{29}$ Soerjono Soekanto. Faktor-Faktor Yang Mempengaruhi Penegakan Hukum, PT. RajaGrafindo Persada. Edisi 1. Cet.4. Jakarta. 2002. hlm. 8.

${ }^{30}$ Marwan Efendi. Kejaksaan RI: Posisi dan Fungsinya dari Perspektif Hukum. PT Gramedia Pustaka Utama. Jakarta, 2005. hlm. 1.
} 
1. Bentuk-bentuk tindak pidana berkaitan dengan limbah bahan berbahaya dan beracun, seperti perbuatan melakukan pengelolaan limbah B3 tanpa izin dan perbuatan yang menghasilkan limbah B3 dan tidak melakukan pengelolaan serta memasukkan limbah B3 ke dalam wilayah Negara Kesatuan Republik Indonesia dan memasukkan B3 yang dilarang menurut peraturan perundangundangan ke dalam wilayah Negara Kesatuan Republik Indonesia, khususnya di bidang Perlindungan dan Pengelolaan Lingkungan Hidup.

2. Pemberlakuan ketentuan pidana terhadap kejahatan berkaitan dengan limbah bahan berbahaya dan beracun, maka pelaku dapat dikenakan pidana penjara dan denda sesuai dengan bentuk-bentuk perbuatan pidana yang telah terbukti secara sah menurut hukum dilakukan oleh pelakunya. Apabila tindak pidana lingkungan hidup dilakukan oleh, untuk, atau atas nama badan usaha, tuntutan pidana dan sanksi pidana dijatuhkan kepada: badan usaha; dan/atau orang yang memberi perintah untuk melakukan tindak pidana tersebut atau orang yang bertindak sebagai pemimpin kegiatan dalam tindak pidana tersebut, sebagaimana diatur dalam Undang-Undang Nomor 32 Tahun 20009 tentang Perlindungan dan Pengelolaan Lingkungan Hidup.

\section{B. Saran}

1. Untuk mencegah terjadinya bentukbentuk tindak pidana berkaitan dengan limbah bahan berbahaya dan beracun, maka diperlukan pengawasan yang efektif oleh Menteri, gubernur, atau bupati/walikota sesuai dengan kewenangannya wajib melakukan pengawasan terhadap ketaatan penanggung jawab usaha dan/atau kegiatan atas ketentuan yang ditetapkan dalam peraturan perundang-undangan di bidang perlindungan dan pengelolaan lingkungan hidup. Bahan berbahaya dan beracun beserta limbahnya perlu dikelola dengan baik. Wilayah Negara Kesatuan Republik Indonesia harus bebas dari buangan limbah bahan berbahaya dan beracun dari luar wilayah Indonesia.

2. Pemberlakuan ketentuan pidana terhadap kejahatan berkaitan dengan limbah bahan berbahaya dan beracun perlu diterapkan sesuai dengan peraturan perundang-undangan yang berlaku guna memberikan efek jera bagi pelakunya dan bagi pihak lain dapat dilakukan upaya pencegahan untuk tidak melakukan perbuatan yang sama karena dapat dikenakan sanksi pidana penjara dan denda.

\section{DAFTAR PUSTAKA}

Efendi Marwan. Kejaksaan Rl: Posisi dan Fungsinya dari Perspektif Hukum. PT Gramedia Pustaka Utama. Jakarta, 2005.

Hadjon. M. Philipus. dkk. Pengantar Hukum Administrasi Indonesia, Gadjah Mada Press University Yogyakarta. 2002.

Hamzah Andi, Terminologi Hukum Pidana, (Editor) Tarmizi, Ed. 1. Cet. 1. Sinar Grafika, Jakarta, 2008.

H. Juniarso Ridwan dan Achmad Sodik Sudrajat. Hukum Adminsitrasi Negara dan Kebijakan Pelayanan Publik, Cetakan I. Nuansa. Bandung. 2010.

HR.Ridwan. Hukum Administrasi Negara. UII Press. Yogyakarta. 2003.

Kumalasari Wahyu Galuh. Konsep Tanggung Jawab Mutlak Pelaku Usaha Dalam Pengelolaan Limbah Bahan Berbahaya dan Beracun Berdasarkan Perspektif Hukum Perdata. Prosiding Seminar Nasional "Tanggung Jawab Pelaku Bisnis dalam Pengelolaan Lingkungan Hidup" ISBN: 978-602361-036-5.

Mahrus Ali, Dasar-Dasar Hukum Pidana, Cetakan Pertama, Sinar Grafika, Jakarta, 2011.

Malia Evi dan Ardiani Vika A. Peranan Dinas Lingkungan Hidup Dalam Pengawasan Penerapan Akuntansi Lingkungan Pada Entitas Bisnis di Kabupaten Pamekasan.Jurnal Akuntansi Universitas Jember. Vol. 17 No. 2 (2019).

Marbun Rocky, Deni Bram, Yuliasara Isnaeni dan Nusya A., Kamus Hukum Lengkap 
(Mencakup Istilah Hukum \& Perundang-Undangan Terbaru, Cetakan Pertama, Visimedia, Jakarta. 2012.

Mardani, Penyalahgunaan Narkoba Dalam Perspektif Hukum Islam Dan Hukum Pidana Nasional, Ed. 1, PT. RajaGrafindo, Jakarta, 2008.

Marbun Rocky, Deni Bram, Yuliasara Isnaeni dan Nusya A., Kamus Hukum Lengkap (Mencakup Istilah Hukum \& Perundang-Undangan Terbaru, Cetakan Pertama, Visimedia, Jakarta. 2012.

Marpaung Leden, Asas-Teori-Praktik Hukum Pidana, Sinar Grafika. Cetakan Kedua, Jakarta, 2005.

Masriani Tiena Yulies. Pengantar Hukum Indonesia, Cetakan Kelima, Sinar Grafika, Jakarta. 2009.

Moeljatno, Asas-Asas Hukum Pidana, Edisi Revisi, PT. Rineka Cipta, Jakarta, 2008.

Nugroho Sapto Sigit. Pengelolaan Limbah Bahan Berbahaya Dan Beracun Perspektif Undang-Undang Nomor 32 Tahun 2009 Tentang Perlindungan Dan Pengelolaan Lingkungan Hidup.Sosial Volume 14 Nomor 2 September 2013.

Nurdin M. Peranan Penyidik Dalam Penegakan Hukum Terhadap Pelanggaran Tindak Pidana Lingkungan Hidup. Volume 12, Nomor 2, Juli-Desember 2017. hlm.172 (Lihat Muhamad Erwin, Hukum Lingkungan Dalam System Kebijaksanaan Pembangunan Lingkungan Hidup, Refika Aditama, Bandung. 2008.

Prasetiawan Teddy. Kebijakan Pelarangan Impor Limbah Bahan Berbahaya Beracun (B3) Dan Permasalahannya (Hazardous Waste Import Ban Policy And Problems).Widyariset, Vol. 15 No.1, April 2012.

Prins W.F dan R. Kosim Adisapoetra, Pengantar Hukum IImu Administrasi Negara. Pradnya Paramita, Jakarta. 1983.

Sadjijono. Polri Dalam Perkembangan Hukum Di Indonesia, (Editor) M. Khoidin, LaksBang PRESSindo, Yogyakarta. 2008.
Sidik Abdurrakhman Ari dan Enri Damanhuri. Studi Pengelolaan Limbah B3 (Bahan Berbahaya Dan Beracun) Laboratorium Laboratorium Di ITB (Study Of Management Of Hazardous Waste In The Laboratories Of ITB) Jurnal Teknik Lingkungan Volume 18 Nomor 1, April 2012 (Hal 12-20).

Sitompul Parsaoran Robinson, Susilo Handoyo dan Roziqin. Pengendalian Pencemaran Bahan Berbahaya Dan Beracun (B3) Di Wilayah Laut Balikpapan (Pollution Of Hazardous And Toxic Materials (B3) In Balikpapan Marine Region). Jurnal Projudice : Jurnal Online Mahasiswa Pascasarjana Uniba.Vol. 1 No. 1, Oktober 2019.

Soedjono. Penegakan Hukum dalam Sistem Pertahanan Sipil, Karya Nusantara. Bandung. 1978.

Soekanto Soerjono. Faktor-faktor Yang Mempengaruhi Penegakkan Hukum. Raja Grafindo Persada. Jakarta. 2007.

Soekanto Soerjono. Faktor-Faktor Yang Mempengaruhi Penegakan Hukum, PT. RajaGrafindo Persada. Edisi 1. Cet.4. Jakarta. 2002.

Spelt N.M. dan J.B.J.M. Ten Berge, Pengantar Hukum Perizinan, (Penyunting) Philipus. M. Hadjon, Yuridika. Surabaya. 1993.

Sudarsono, Kamus Hukum, Cetakan Keenam, PT. Rineka Cipta, Jakarta, 2009.

Sutedi Adrian. Hukum Perizinan Dalam Sektor Pelayanan Publik, Sinar Grafika. Jakarta. 2011.

Sunarso Siswantoro, Hukum Pidana Lingkungan Hidup Dan Strategi Penyelesaian Sengketa, Cetakan Pertama, Rineka Cipta, Jakarta, 2005.

Sutedi Adrian. Hukum Perizinan dalam Sektor Pelayanan Publik. Sinar Grafika. Jakarta. 2009.

Syahrin Alvi, Beberapa Isu Hukum Lingkungan Kepidanaan, Cetakan Revisi, PT. Sofmedia, Jakarta, 2009.

Syamsuddin Aziz. Tindak Pidana Khusus. Sinar Grafika. Jakarta. 2011.

Wibawa Putu Sastra I.. Politik Hukum Perlindungan Dan Pengelolaan Lingkungan Menuju Ekokrasi 
Indonesia (legal Politic Of Protection And Management of Environment Heading To Indonesia Ecocracy) Kanun Jurnal Ilmu Hukum. Vol. 18, No. 1, (April, 2016).ISSN: 0854-5499.

Yamin Muhammad, Tindak Pidana Khusus, Cet.

1. Pustaka Setia, Bandung, 2012.

\section{Peraturan Perundang-Undangan}

Undang-Undang Nomor 32 Tahun 2009

Tentang Perlindungan Dan Pengelolaan

Lingkungan Hidup.

Peraturan Pemerintah Republik Indonesia

Nomor 101 Tahun 2014 Tentang Pengelolaan

Limbah Bahan Berbahaya Dan Beracun. 